Walk, Don't Run - to Online Learning

By: Wayne Journell

Journell, W. (2012). Walk, don’t run—to online learning. Phi Delta Kappan, 93(7), 46-50.

****(C) Phi Delta Kappa International. Reprinted with permission. No further reproduction is authorized without written permission from SAGE Publications. This version of the document is not the version of record. Figures and/or pictures may be missing from this format of the document. $* * *$

Made available courtesy of SAGE Publications:

http://dx.doi.org/10.1177/003172171209300711

\title{
Abstract:
}

The financial lure of lower-cost online learning during a period of tight budgets shouldn't prompt schools to proceed before giving serious consideration to a multitude of factors.

In 2003, my first year of teaching high school, the district technology representative approached me about creating an online U.S. Government course that would become one of the first courses offered in the district's new e-learning program. My district had prided itself on being on the cutting edge of technological advancements. At the time, it was one of the few districts in Virginia to maintain a one-to-one laptop initiative, and all courses had been equipped with Blackboard course management software. An e-learning program was the next step in this evolution. I agreed to create the course that summer and taught it about 12 times over the next four years. My class sizes ranged from one student who needed to take the class to satisfy a graduation requirement to more than 20 students in summer sessions.

Keywords: online learning | online education | secondary school teachers | U.S. government course | virtual high school program | K-12 administrators |K-12 education

Article: 
The financial lure of lower-cost online learning during a period of tight budgets shouldn't prompt schools to proceed before giving serious consideration to a multitude of factors.

In 2003, my first year of teaching high school, the district technology representative approached me about creating an online U.S. Government course that would become one of the first courses offered in the district's new e-learning program. My district had prided itself on being on the cutting edge of technological advancements. At the time, it was one of the few districts in Virginia to maintain a one-to-one laptop initiative, and all courses had been equipped with Blackboard course management software. An e-learning program was the next step in this evolution. I agreed to create the course that summer and taught it about 12 times over the next four years. My class sizes ranged from one student who needed to take the class to satisfy a graduation requirement to more than 20 students in summer sessions.

My district implemented online education to embrace the anytime, anywhere learning environment that was gaining popularity in higher education. The district advertised the program as a way for homebound and nontraditional students to earn course credits without coming to school and for giving students flexibility to take summer courses without keeping them from jobs or vacations. Within a few years, however, the district began designating some courses as online only during the summer in order to reduce costs and maximize online enrollment.

Over the past decade, as states and localities began feeling the effects of rising gas prices and a crumbling economy, more districts have begun to regard online education as a way to save money. Nearly every state has some form of virtual high school program (Schrum, 2004), and many districts are creating their own online courses. In 2006, Michigan even took the unprecedented step of requiring all students to take at least one online course during high school.

Online education is a favorable alternative to firing personnel or cutting programs, but district leaders should proceed cautiously. Online learning may be cheaper than traditional schooling, but it isn't necessarily equivalent to face-to-face instruction, nor is it an appropriate substitute in every case for classroom instruction for adolescents.

\section{Benefits of online learning}

What makes online learning so attractive to school districts is perceived cost efficiency, at least in the long term. Once appropriate supports are established, including teacher training, e-learning theoretically enables districts to manage increasing enrollments without creating additional infrastructure. Certain courses, especially those with low enrollments, could also be moved online to create additional classroom space in crowded schools. Moreover, as technology improves and gets into more students' hands, the cost of online learning will decrease.

Beyond cost efficiency, online learning offers other potential benefits to K-12 schooling, principally as an education path for homebound students and as a way for students who have difficulty with traditional educational environments to interact with peers. Considerable research on e-learning in higher education has also shown that when students take courses online, many of the discriminatory factors that occur in face-to-face classes are alleviated (Coombs, 2005; Enger, 2006; Davidson-Shivers, Morris, \& Sriwongkol, 2003). 
Online learning may be cheaper than traditional schooling, but it isn't necessarily equivalent to face-to-face instruction nor appropriate for all students.

Also, it has been argued that online education could be used to bridge gaps between affluent districts and districts in low-income urban and rural areas (Journell, 2007). E-learning promotes curricular democratization in which all students are privy to the same types of academic options. Some states already have used their virtual high schools to make Advanced Placement courses and other electives available to inner-city students who would be unable to take them otherwise (Blaylock \& Newman, 2005).

\section{Proceeding cautiously}

While shrinking budgets entice districts, K-12 administrators interested in exploring online instruction should proceed cautiously. Notwithstanding online learning's success in higher education, it remains a relatively new medium for teaching and learning that is constantly being improved based on research. Currently, little research documents pedagogical outcomes of online instruction in precollegiate environments. The extant research suggests that implementing online instruction to adolescents will require considerable education and training for students and teachers.

Perhaps the first challenge that districts must address is the perception that online learning is an easy way to bypass the type of engaged learning one would typically find in a face-to-face class. In a study of an online high school U.S. History class, I found that many students took the course because they didn't particularly care for the subject and thought it would be a quick and painless way to earn class credit without having to immerse themselves in the content. The teacher shared this perception, saying that he believed the primary function of the course was to disseminate content as opposed to really getting students interested in the topic. He also believed his online students were uninterested in social aspects of instruction, such as discussion, and were only concerned with learning enough to pass the course and the state-mandated end-of-course assessment (Journell, 2008, 2010). To avoid having online programs regress into the digital diploma mills chastised by Noble (2001) and others, districts will need to correct these types of misconceptions by educating students and faculty about the realities of online education.

Related to that issue is teacher training. When my district approached me to design that online U.S. Government course, I had taken only a couple online courses as part of my master's degree program and had no training for teaching online. My superiors viewed me as an effective classroom teacher and assumed I could transfer my instruction online, an assumption that's rarely correct. Too often, instructors are asked to teach online because they have been recognized by administrators as being exceptional classroom teachers or being particularly adept at technology, neither of which automatically translates into effective online pedagogy. Online instruction requires a different skill set and dispositions (Garrison \& Anderson, 2003; Journell, 2008; Quinlan, 2011). 


\section{Beyond content dissemination}

If districts choose to move programs online, they must provide teachers with sufficient learning opportunities to explore the various nuances of online instruction, such as creating classroom community, learning to implement synchronous and asynchronous communication, and assessing student performance. To move online courses beyond content dissemination, teachers must know how to promote reflective, constructivist learning online - a process that may look different than what is typically done in a face-to-face class (Berge, 2002; Buraphadeja \& Dawson, 2008; Garrison \& Cleveland-Innis, 2005). Of course, there is a limit to how much professional development districts can be expected to provide in this area since most online teachers probably won't teach exclusively online. If online K-12 education continues to gain traction in the United States, university teacher education programs will need to include courses in online pedagogy as part of their standard curriculum (Davis \& Roblyer, 2005).

Students also must learn what to expect from online instruction. They must know that online courses aren't designed to avoid social interaction and engagement with content. Rather, students should get instructions on the habits needed for successful online experiences as well as examples of how to communicate with classmates and teachers on a regular basis. Research in higher education has shown that requiring students to attend at least one face-to-face meeting with the teacher and their classmates before starting an online course leads to a greater sense of community and greater academic success among students (Haythornthwaite, Kazmer, Robbins, \& Shoemaker, 2004).

Students also must recognize how much intrinsic motivation is required to be successful in online courses. Based on research among adult learners, online courses, on average, have higher dropout rates than face-to-face classes, and the main reasons students fail online classes is because they simply stop doing work and "disappear" (Jun, 2005). Research suggests that many younger students lack the requisite intrinsic motivation needed to succeed online, especially when compared to older students (Hoskins \& van Hooff, 2005; Weiner, 2003). Secondary students in particular may need the constant reinforcement and reminders that occur in face-toface classes and may have difficulty succeeding in an online environment where the teacher is not physically present.

Therefore, allowing students to choose whether to take courses online is probably advisable. Forcing students to take courses online may set up less intrinsically motivated students for failure. Moreover, before students register for online courses, have them take a type of personality test that can predict their level of success based on their answers to questions probing their learning preferences and styles (Roblyer 1999; Roblyer, Davis, Mills, Marshall, \& Pape, 2008). Then, students can be better counseled into online or face-to-face courses based on their academic strengths and weaknesses. Districts should always market their online courses by noting that online instruction is not for everyone.

Of course, no matter how much training and preparation students and faculty receive, there will always be issues that must be addressed on a case-by-case basis. For example, even though the Internet has become ubiquitous in American society, some geographic areas and households still don't have regular access to computers or high-speed Internet connections. Certainly, students 
who don't have technology at home could be expected to complete online courses at school or other areas where technology is available, such as a public library, but these accommodations may create transportation issues for students and their parents. The greater concern is that a secondary digital divide has developed in the U.S. - one defined less by access and more by the lack of technological literacy. The nature of the digital divide coupled with ever-changing technology advancements means individuals who find themselves on the wrong end of the divide will stay there (Haythornthwaite, 2007). Students who fall into this category will need additional support if they choose to take courses online.

Finally, one aspect of online learning that hasn't received much attention in the literature is how online courses should be adapted to accommodate students with special needs. Too often, online courses are created with a "one size fits all" approach that doesn't allow for differentiated instruction (Keeler \& Horney, 2007). If online learning is to be a viable alternative to face-toface K-12 instruction in the U.S., districts must take appropriate steps to ensure that their courses meet the needs of English language learners and students with special needs.

\section{Conclusion}

Online learning is most likely the future of public education in the United States, which may actually be beneficial given the Internet's potential to equalize academic opportunities. To stand in the path of a moving train is as unproductive as it is foolish.

However, we must be realistic about the effect of the current budget crisis on public education in the United States. Districts must be creative in their attempts to save money, but history has shown that when education reform is prompted by knee-jerk reactions to external financial or social pressures, the result rarely leads to positive education outcomes for students. Simply throwing programs online in a quick attempt to save money is not the answer. Online courses must be comparable to face-to-face instruction in terms of rigor and opportunities for engaged learning - outcomes that can occur only if districts proceed cautiously and spend the time and money necessary to build sufficient infrastructure and train personnel in best practices of online pedagogy.

\section{References}

Berge Z. (2002). Active, interactive, and reflective learning. Quarterly Review of Distance Education, 3, 181-190.

Blaylock T., Newman J. (2005). The impact of computer-based secondary education. Education, $125,373-384$.

Buraphadeja V., Dawson K. (2008). Content analysis in computer-mediated communication: Analyzing models for assessing critical thinking through the lens of social constructivism. American Journal of Distance Education, 22, 130-145. 
Coombs N. (2005). Transcending distances and differences with online learning. In Kearsley G. (Ed.), Online learning: Personal reflections on the transformation of education (pp. 5365). Englewood Cliffs, NJ: Educational Technology Publications.

Davidson-Shivers G., Morris S., Sriwongkol T. (2003). Gender differences: Are they diminished in online discussions? International Journal on E-Learning, 2, 29-36.

Davis N., Roblyer M. (2005). Preparing teachers for the 'schools that technology built': Evaluation of a program to train teachers in virtual schooling. Journal of Research in Technology in Education, 37, 399-409.

Enger K. (2006). Minorities and online higher education. Educause Quarterly, 4, 7-8.

Garrison D., Anderson T. (2003). E-learning in the 21st century: A framework for research and practice.London, England: RoutledgeFalmer.

Garrison D., Cleveland-Innis M. (2005). Facilitating cognitive presence in online learning: Interaction is not enough. American Journal of Distance Education, 19, 133-148.

Haythornthwaite C. (2007). Digital divide and e-learning. In Andrews R., Haythornthwaite C. (Eds.), The Sage handbook of e-learning research (pp. 97-118). London, England: Sage.

Haythornthwaite C., Kazmer M., Robbins J., Shoemaker S. (2004). Community development among distance learners: Temporal and technological dimensions. In Haythornthwaite C., Kazmer M. (Eds.), Learning, culture, and community in online education: Research and practice (pp. 35-57). New York, NY: Peter Lang.

Hoskins S., van Hooff J. (2005). Motivation and ability: Which students use online learning and what influence does it have on their achievement? British Journal of Educational Technology, $36,177-192$.

Journell W. (2007). The inequities of the digital divide: Is e-learning a solution? E-Learning, $4,138-149$.

Journell W. (2008). Facilitating historical discussions using asynchronous communication: The role of the teacher. Theory and Research in Social Education, 36, 317-355.

Journell W. (2010). Perceptions of e-learning in secondary education: A viable alternative to classroom instruction or a way to bypass engaged learning? Educational Media International, 47, 69-81.

Jun J. (2005). Understanding e-dropout. International Journal on E-Learning, 4, 229-240.

Keeler C., Horney M. (2007). Online course design: Are special needs being met? American Journal of Distance Education, 21, 61-75. 
Noble D. (2001). Digital diploma mills: The automation of higher education. New York, NY: Monthly Review Press.

Quinlan A. (2011). 12 tips for the online teacher. Phi Delta Kappan, 92 (4), 28-31.

Roblyer M. (1999). Is choice important in distance learning? A study of student motives for taking Internet-based courses at the high school and community college levels. Journal of Research on Computing in Education, 32, 157-171.

Roblyer M., Davis L., Mills S., Marshall J., Pape L. (2008). Toward practical procedures for predicting and promoting success in virtual school students. American Journal of Distance Education, 22, 90-109.

Schrum L. (2004). The web and virtual schools. Computers in the Schools, 21, 81-89.

Weiner C. (2003). Key ingredients to online learning: Adolescent students study in cyberspace — the nature of the study. International Journal on E-Learning, 2, 44-50. 